\title{
Aerosol layer heights above Tajikistan during the CADEX campaign
}

\author{
Julian Hofer ${ }^{1, *}$, Dietrich Althausen ${ }^{1}$, Sabur F. Abdullaev ${ }^{2}$, Bakhron I. Nazarov², Abduvosit N. Makhmudov ${ }^{2}$, Holger \\ Baars $^{1}$, Ronny Engelmann ${ }^{1}$, and Albert Ansmann ${ }^{1}$ \\ ${ }^{1}$ Leibniz Institute for Tropospheric Research, Leipzig, Germany \\ ${ }^{2}$ Physical Technical Institute of the Academy of Sciences of Tajikistan, Dushanbe, Tajikistan
}

\begin{abstract}
Mineral dust influences climate and weather by direct and indirect effects. Surrounded by dust sources, Central Asian countries are affected by atmospheric mineral dust on a regular basis. Climate change effects like glacier retreat and desertification are prevalent in Central Asia as well. Therefore, the role of dust in the climate system in Central Asia needs to be clarified and quantified. During the Central Asian Dust EXperiment (CADEX) first lidar observations in Tajikistan were conducted. Long-term vertically resolved aerosol measurements were performed with the multiwavelength polarization Raman lidar Polly ${ }^{\mathrm{XT}}$ from March 2015 to August 2016 in Dushanbe, Tajikistan. In this contribution, a climatology of the aerosol layer heights is presented, which was retrieved from the 18-month lidar measurements. Automatic detection based on backscatter coefficient thresholds were used to retrieve the aerosol layer heights and yield similar layer heights as manual layer height determination. The significant aerosol layer height has a maximum in summer and a minimum in winter. The highest layers occurred in spring, but in summer uppermost layer heights above $6 \mathrm{~km}$ AGL are frequent, too.
\end{abstract}

\section{Introduction}

Central Asia is frequently affected by atmospheric mineral dust due to its location in the center of the global dust belt, that is reaching from the Sahara to the Gobi desert [1]. The dust has an impact on climate (by direct and indirect effects) [2,3], environmental conditions, ecosystems, and human health [4]. Therefore aerosol observations in Tajikistan are highly important to understand regional and global transport of mineral dust and its effects on climate. In particular, the properties of African and West-Asian dust on their transport to East Asia are of interest, since they are subject to strong anthropogenic influence [5]. Little is known about the vertical structure of the aerosol and especially the transport of mineral dust above Central Asia [6-8]. Therefore CADEX was conducted to provide longterm data on vertical profiles of optical aerosol properties [9]. The measurements show strong near-ground dust and lofted layers contributing significantly to the aerosol optical thickness, as well as thinner lofted layers at very high altitudes [9]. The optical and geometric properties of these dust layers are a crucial information for radiativetransfer calculations [10], while the thinner high-altitude dust layers are essential for aerosol-cloud interaction studies $[11,12]$. Therefore, this contribution presents a climatology of the aerosol layer heights retrieved from 18month lidar measurements during the CADEX campaign in Dushanbe, Tajikistan.

\section{Methods and Data}

\subsection{Instruments and measurements}

The CADEX campaign was conducted from March 2015 until August 2016 in Dushanbe. The field site at the Physical Technical Institute of the Academy of Science of Tajikistan is located at $38^{\circ} 33^{\prime} 34^{\prime \prime} \mathrm{N}, 68^{\circ} 51^{\prime} 22^{\prime \prime} \mathrm{E}$ at an altitude of $864 \mathrm{~m} \mathrm{ASL} \mathrm{[9].} \mathrm{The} \mathrm{measurements} \mathrm{were} \mathrm{per-}$ formed with the multiwavelength polarization Raman lidar Polly ${ }^{X T}$ [13] as part of PollyNET [14]. The Polly ${ }^{X T}$ emits laser pulses at $355 \mathrm{~nm}, 532 \mathrm{~nm}$, and $1064 \mathrm{~nm}$ wavelength. Vertical profiles of the particle backscatter coefficient are determined at these three emitted wavelengths. Cross-polarized detection channels at $355 \mathrm{~nm}$ and $532 \mathrm{~nm}$ wavelength are installed to retrieve the particle depolarization ratios. Particle extinction coefficients at $355 \mathrm{~nm}$ and $532 \mathrm{~nm}$ are calculated with the Raman method [15] using the inelastic channels at $387 \mathrm{~nm}$ and $607 \mathrm{~nm}$ at night-time. For water vapor measurements, a channel at $407 \mathrm{~nm}$ is installed. It is calibrated using the CIMEL sun photometer [16] from the AERONET (AErosol RObotic NETwork) [17] station in Dushanbe, which is collocated with the Polly ${ }^{\mathrm{XT}}$ lidar. The sun photometer measures the aerosol optical thickness and retrieves further particle properties, such as size distribution, fine and coarse mode fraction. During the period of the CADEX campaign, at 487 days lidar data have been acquired for a duration of at least $3 \mathrm{~h}$. On 308 out of those days, the lidar ran for more than $20 \mathrm{~h}$.

\footnotetext{
*Corresponding author: hofer@tropos.de
} 

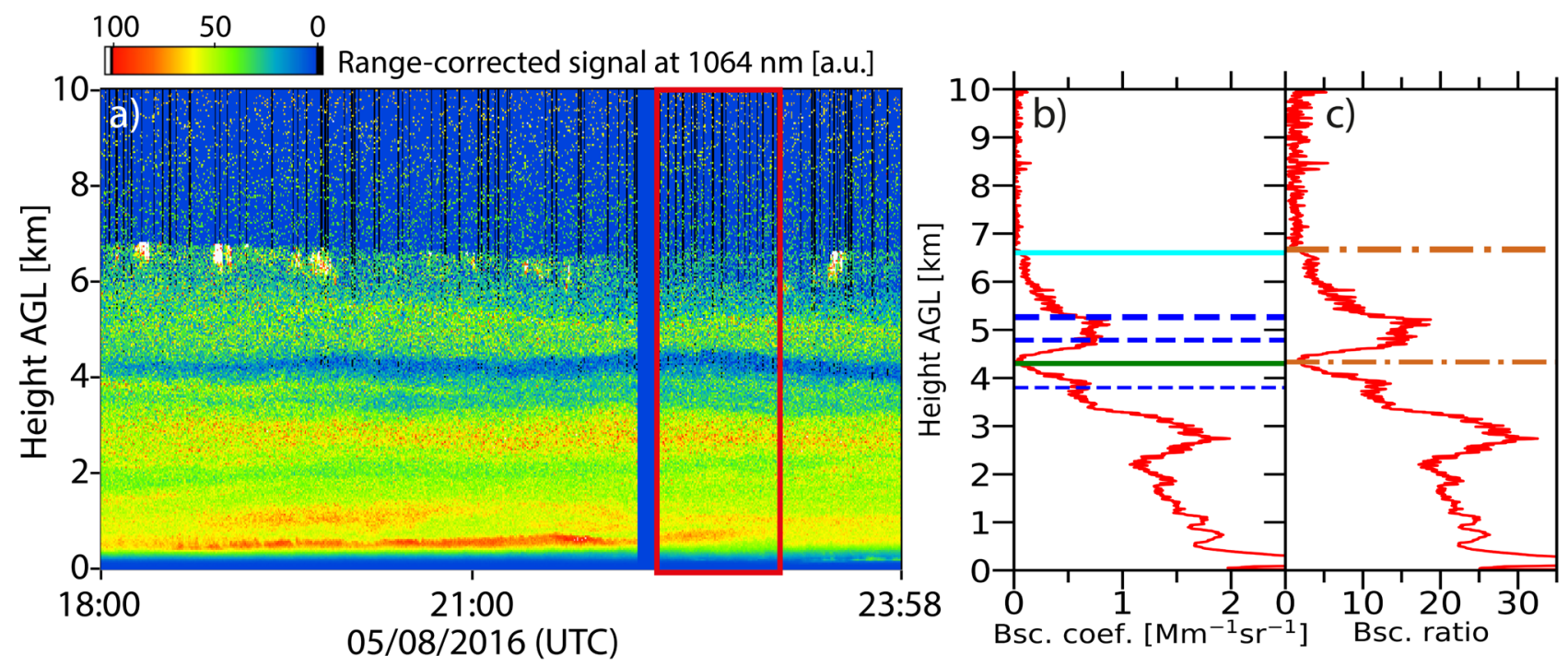

Figure 1. Measurement example from 5 August 2016. a) Temporal development of the range-corrected signal at $1064 \mathrm{~nm}$ wavelength on 5 August 2016, 18:00-23:58 UTC. Red box: averaging period for calculation of the profiles (5 August 2016, 22:10-22:59 UTC). Blue bar: no measurements, due to automatic depolarization calibration. b) Particle backscatter coefficient at $1064 \mathrm{~nm}$ wavelength with $22.5 \mathrm{~m}$ vertical smoothing length. Light blue line: manually determined uppermost layer height. Green line: manually determined significant aerosol height. Blue dashed lines: integrated backscatter heights (see text). c) Backscatter ratio at $1064 \mathrm{~nm}$. Brown lines: backscatter ratio threshold heights (see text).

\subsection{Data analysis and layer heights determination}

The basis of this study are 268 manually analyzed profiles of the optical properties above Tajikistan. They were individually calculated at each night at which it was possible to apply the Raman method.

The analyzed profiles were used to asses the aerosol stratification above Tajikistan by defining the following aerosol top heights. By visual inspection of the profiles, a significant aerosol layer height was defined where the backscatter coefficient at $1064 \mathrm{~nm}$ reaches a first minimum in a range between about $0-1.5 \cdot 10^{-4} \mathrm{~km}^{-1} \mathrm{sr}^{-1}$. If an aerosol layer at a higher altitude was present above the significant aerosol layer height, an uppermost layer height was defined where the backscatter coefficient decreases again to a range between about $0-5 \cdot 10^{-5} \mathrm{~km}^{-1} \mathrm{sr}^{-1}$.

Since this is to a certain degree arbitrary, more objective automatic layer detection methods were applied too. Threshold methods on the backscatter ratio as well as on the backscatter coefficient at $1064 \mathrm{~nm}$ wavelength were applied. Furthermore, the backscatter coefficient at $1064 \mathrm{~nm}$ was integrated and the heights were calculated at which certain percentages of the total integrated backscatter were reached.

Figure 1a shows the temporal development of the range corrected-signal at $1064 \mathrm{~nm}$ wavelength of an exemplary measurement on 5 August 2016, where a lofted aerosol layer occurred. Figure $1 \mathrm{~b}$ shows the profile of the particle backscatter coefficient at $1064 \mathrm{~nm}$ wavelength and Fig. 1c shows the profile of the backscatter ratio at $1064 \mathrm{~nm}$ wavelength.

The blue dashed lines in Fig. 1b denote the height where $85 \%$ (thinnest), 90\%, and 95\% (thickest) of the total integrated backscatter is reached. The brown dash-dotted lines in Fig. 1c denote the heights where the backscatter ratio decreases below the threshold of 1.8 (thinner) and 1.2 (thicker). The light blue line in Fig. 1b denotes the manually determined height of the uppermost aerosol layer and the green line denotes the manually determined significant aerosol height.

The backscatter ratio threshold of 1.8 yields a height close to the manually determined significant aerosol height at $4.3 \mathrm{~km}$. In this case, this is similar to the height determined by a backscatter coefficient threshold of $1 \cdot 10^{-4} \mathrm{~km}^{-1} \mathrm{sr}^{-1}$. The smaller backscatter ratio threshold of 1.2 yields a larger height close to the manually determined uppermost aerosol layer height at $6.6 \mathrm{~km}$. The height of $85 \%$ integrated backscatter covers most of the significant aerosol, while the 90 and $95 \%$ heights are only reached within the lofted layer.

\section{Results}

The procedure described in Sec. 2.2 was applied to all 268 profiles from March 2015 until August 2016. The resulting aerosol layer heights are presented in Fig. 2. The significant aerosol height shows a clear annual cycle during 2015. It is increasing from spring to a maximum during July and then decreasing until November. Due to cloudy conditions only few profiles could be retrieved in the winter months. In general, lower significant aerosol heights were observed during these months. From February to March 2016 a continuous increase in the significant aerosol height occurred. Afterward the significant aerosol heights show variability but no decreasing tendency in August 2016. July 2016 has lower significant aerosol heights than July 2015, but August 2016 has on 


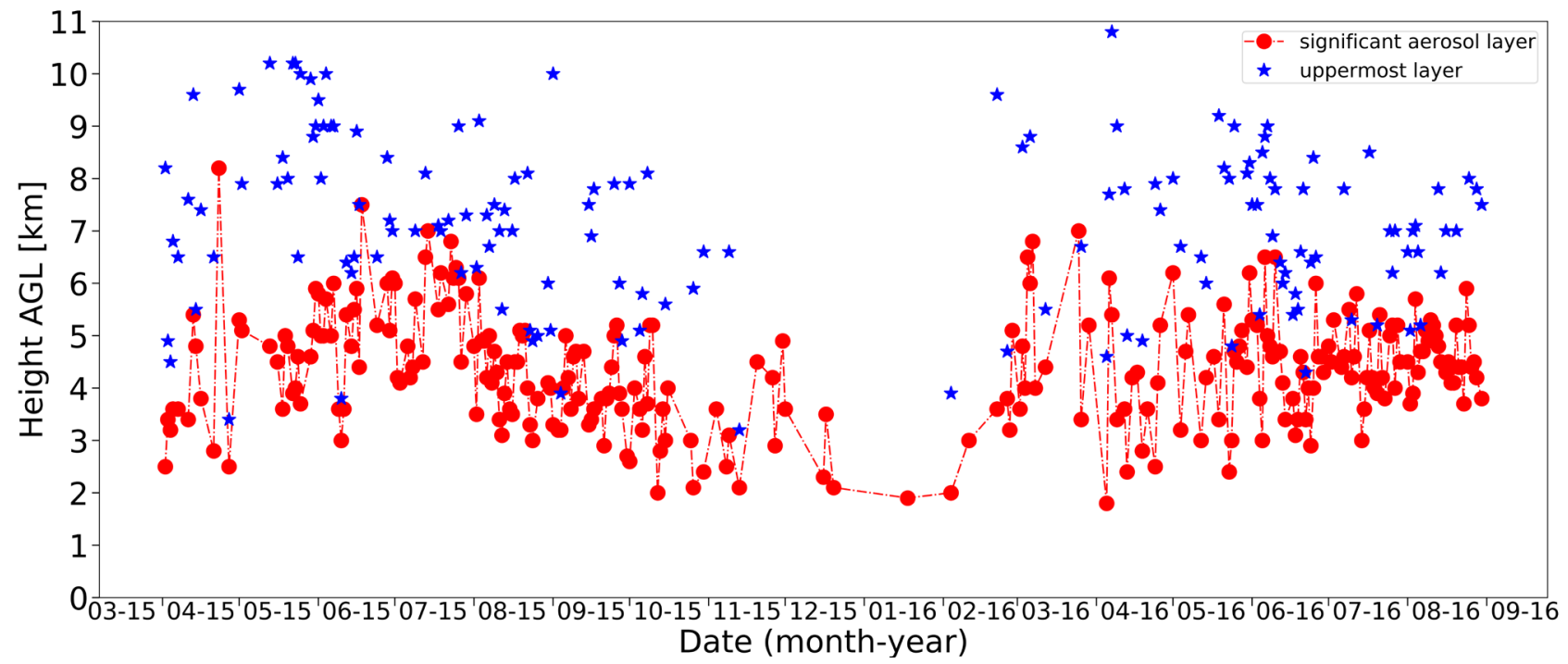

Figure 2. Time series of the determined layer top heights from March 2015 to August 2016. Red connected dots: manually determined top height of the significant aerosol. Blue stars: top height of the uppermost aerosol layer (not occurring in each case).

average higher significant aerosol layer heights than August 2015. The uppermost layer heights show a decreasing tendency from spring to autumn 2015, with frequent layers above $6 \mathrm{~km}$ and most of the values above $9 \mathrm{~km}$ in April and May 2015. In the winter months almost no high-altitude aerosol layers occurred. The uppermost layer heights in 2016 were comparable to the ones in 2015, but with less very high layers above $9 \mathrm{~km}$ in spring 2016 compared to 2015. In general, the automatically determined layer heights with a backscatter coefficient threshold of $1 \cdot 10^{-4} \mathrm{~km}^{-1} \mathrm{sr}^{-1}$ and the layer heights determined with a backscatter ratio threshold of 1.8 fit well with the manually determined significant aerosol heights.

\section{Discussion and Outlook}

The top height of the significant aerosol layer in summer is mostly above $3 \mathrm{~km}$ and during extended periods even above $4 \mathrm{~km}$ height. This compares well with previous observations in the vicinity. Lidar observations in spring in Aksu (northwestern Taklamakan desert) showed typical heights of dust layers of about $2.5-5.5 \mathrm{~km}$, but without higher lofted layers $[18,19]$. A maximum of the significant aerosol height in July has been also observed in Kyrgyzstan [20], but the significant aerosol was mostly confined below 4-4.5 km [8], at a higher elevated observatory though, while long-range transported dust was reported above $7.6 \mathrm{~km}$ height [8].

In winter and autumn the significant aerosol layer height is between $2 \mathrm{~km}$ and occasionally $5 \mathrm{~km}$ above Tajikistan. The observed heights are partially also higher than at a likewise anthropologically polluted place, the Pearl River Delta, Guangzhou, China [21, 22]. At that place, haze layer heights in October were measured up to $1.5-3 \mathrm{~km}$, in November to February mostly below $2.5 \mathrm{~km}$, and in spring up to $3.5 \mathrm{~km}$. In summer (May-June) top heights between $2.5-3 \mathrm{~km}$ occurred there, but also lofted layers up to $5 \mathrm{~km}[21,22]$.

Except in late autumn and winter, high-altitude dust layers reaching heights of more than $7 \mathrm{~km}$ AGL were observed above the measurement site throughout the year. As westerly winds prevail in the aerosol layer heights, these high layers can cross over the barriers like the Pamir (7.6 km ASL) and Tien Shan mountains (7.4 km ASL) and get transported further eastwards. This confirms similar observations in the Taklamakan desert [23] and in Japan as well as model simulations of dust transport to Japan [24], where in a particular case $50 \%$ of the dust particles were estimated to come from the Sahara, 30\% from the Middle East, and only 10\% from China.

Backward trajectory analyses, AERONET data, and the additional optical properties measured by lidar (lidar ratio, particle linear depolarization ratio, Ångström exponent) will be used to investigate the various particle types/mixtures above Tajikistan. Further analyses will also include the extinction profiles to describe the vertical distribution of the aerosol optical thickness above Tajikistan. On the basis of the backscatter and depolarization profiles, estimations about the amount of ice nucleating particles can be made [25-27]. This is especially of interest, since the 18-month data set allows to put these estimations in a climatological context. To provide an even longer time series, preparations to establish a permanent Raman lidar station in Dushanbe are ongoing.

Acknowledgments: The CADEX project was funded by the German Federal Ministry of Education and Research (BMBF) in the context of "Partnerships for sustainable problem solving in emerging and developing countries" under the grant number 01DK14014. This project has also received funding from the European Union's Horizon 2020 research and innovation programme under grant agreement No 654109. 


\section{References}

[1] D.A. Ridley, C.L. Heald, J.F. Kok, C. Zhao, Atmos. Chem. Phys. 16, 15097-15117 (2016)

[2] J.F. Kok, D.S. Ward, N.M. Mahowald, A.T. Evan, Nat. Commun. 9, 241 (2018)

[3] J. Huang, T. Wang, W. Wang, Z. Li, H. Yan, J. Geophys. Res. Atmos. 119, 11398-11416 (2014)

[4] G.F.S. Wiggs, S.L. O'hara, J. Wegerdt, J. Van Der Meer, I. Small, R. Hubbard, Geogr. J. 169, 142157 (2003)

[5] J. Bi, J. Huang, B. Holben, G. Zhang, Atmos. Chem. Phys. 16, 15501-15516 (2016)

[6] G. Golitsyn, D.A. Gillette, Atmos. Environ. 27, 2467-2470 (1993)

[7] M.V. Pachenko, S.A. Terpugova, B.A. Bodhaine, A.A. Isakov, M.A. Sviridenkov, I.N. Sokolik, E.V. Romashova, B.I. Nazarov, A.K. Shukurov, E.I. Chistyakova, T.C. Johnson, Atmos. Environ. 27, 2503-2508 (1993)

[8] B.B. Chen, L.G. Sverdlik, S.A. Imashev, P.A. Solomon, J. Lantz, J.J. Schauer, M.M. Shafer, M.S. Artamonova, G.R. Carmichael, Int. J. Atmos. Sci., 261546 (2013)

[9] J. Hofer, D. Althausen, S.F. Abdullaev, A.N. Makhmudov, B.I. Nazarov, G. Schettler, R. Engelmann, H. Baars, K.W. Fomba, K. Müller, B. Heinold, K. Kandler, A. Ansmann, Atmos. Chem. Phys. 17, 14559-14577 (2017)

[10] Z. Kipling, P. Stier, C.E. Johnson, G.W. Mann, N. Bellouin, S.E. Bauer, T. Bergman, M. Chin, T. Diehl, S.J. Ghan, T. Iversen, A. Kirkevåg, H. Kokkola, X. Liu, G. Luo, T. van Noije, K.J. Pringle, K. von Salzen, M. Schulz, Ø. Seland, R.B. Skeie, T. Takemura, K. Tsigaridis, K. Zhang, Atmos. Chem. Phys. 16, 2221-2241 (2016)

[11] J.E. Yorks, M. McGill, S. Rodier, M. Vaughan, Y. Hu, D. Hlavka, J. Geophys. Res. Atmos. 114, D00H04 (2009)

[12] J.M. Creamean, K.J. Suski, D. Rosenfeld, A. Cazorla, P.J. DeMott, R.C. Sullivan, A.B. White, F.M. Ralph, P. Minnis, J.M. Comstock, J.M. Tomlinson, K.A. Prather, Science 339, 1572-1578 (2013)

[13] R. Engelmann, T. Kanitz, H. Baars, B. Heese, D. Althausen, A. Skupin, U. Wandinger, M. Komppula, I.S. Stachlewska, V. Amiridis, E. Marinou, I. Mattis, H. Linné, A. Ansmann, Atmos. Meas. Tech. 9, 1767-1784 (2016)

[14] H. Baars, T. Kanitz, R. Engelmann, D. Althausen, B. Heese, M. Komppula, J. Preißler, M. Tesche, A. Ansmann, U. Wandinger, J.-H. Lim, J.Y. Ahn, I.S. Stachlewska, V. Amiridis, E. Marinou, P. Seifert, J. Hofer, A. Skupin, F. Schneider, S. Bohlmann, A. Foth, S. Bley, A. Pfüller, E. Giannakaki, H. Lihavainen, Y. Viisanen, R.K. Hooda, S.N. Pereira,
D. Bortoli, F. Wagner, I. Mattis, L. Janicka, K.M. Markowicz, P. Achtert, P. Artaxo, T. Pauliquevis, R.A.F. Souza, V.P. Sharma, P.G. van Zyl, J.P. Beukes, J. Sun, E.G. Rohwer, R. Deng, R.E. Mamouri, F. Zamorano, Atmos. Chem. Phys. 16, 5111-5137 (2016)

[15] A. Ansmann, U. Wandinger, M.A. Riebesell, C. Weitkamp, W. Michaelis, Appl. Opt. 31, 71137131 (1992)

[16] G. Dai, D. Althausen, J. Hofer, R. Engelmann, P. Seifert, J. Bühl, R.E. Mamouri, S. Wu, A. Ansmann, Atmos. Meas. Tech. 11, 2735-2748 (2018)

[17] B.N. Holben, D. Tanré, A. Smirnov, T.F. Eck, I. Slutsker, N. Abuhassan, W.W. Newcomb, J.S. Schafer, B. Chatenet, F. Lavenu, Y.J. Kaufman, J. Castle Vande, A. Setzer, B. Markham, D. Clark, R. Frouin, R. Halthore, A. Karneli, N.T. O’Neill, C. Pietras, R.T. Pinker, K. Voss, G. Zibordi, J. Geophys. Res. Atmos. 106, 12067-12097 (2001)

[18] K. Kai, Y. Nagata, N. Tsunematsu, T. Matsumura, H.-S. Kim, T. Matsumoto, S. Hu, H. Zhou, M. Abo, T. Nagai, J. Meteor. Soc. Japan 86, 1-18 (2008)

[19] N. Tsunematsu, T. Sato, F. Kimura, K. Kai, Y. Kurosaki, T. Nagai, H. Zhou, M. Mikami, J. Geophys. Res. Atmos. 110, D21207 (2005)

[20] B. Chen, L. Sverdlik, International Conf. on Lasers, Applications, and Technologies 2007: Environmental Monitoring and Ecological Applications; Optical Sensors in Bio, Chemical, and Engineering Technologies; and Femtosecond Laser Pulse Filamentation 6733 (2007)

[21] A. Ansmann, R. Engelmann, D. Althausen, U. Wandinger, M. Hu, Y. Zhang, Q. He, Geophys. Res. Lett. 32, L13815 (2005)

[22] B. Heese, H. Baars, S. Bohlmann, D. Althausen, R. Deng, Atmos. Chem. Phys. 17, 6679-6691 (2017)

[23] M. Mikami, G.Y. Shi, I. Uno, S. Yabuki, Y. Iwasaka, M. Yasui, T. Aoki, T.Y. Tanaka, Y. Kurosaki, K. Masuda, A. Uchiyama, A. Matsuki, T. Sakai, T. Takemi, M. Nakawo, N. Seino, M. Ishizuka, S. Satake, K. Fujita, Y. Hara, K. Kai, S. Kanayama, M. Hayashi, M. Du, Y. Kanai, Y. Yamada, X.Y. Zhang, Z. Shen, H. Zhou, O. Abe, T. Nagai, Y. Tsutsumi, M. Chiba, J. Suzuk, Glob. Planet. Change 52, 142-172 (2006)

[24] T.Y. Tanaka, Y. Kurosaki, M. Chiba, T. Matsumura, A. Nagai, T. Yamazaki, A. Uchiyama, N. Tsunematsu, K. Kai, Atmos. Environ. 39, 3901-3909 (2005)

[25] A. Ansmann, R.E. Mamouri, Atmos. Chem. Phys. 15, 3463-3477 (2015)

[26] A. Ansmann, R.E. Mamouri, Atmos. Chem. Phys. 16, 5905-5931 (2016)

[27] R.E. Mamouri, A. Ansmann, Atmos. Meas. Tech. 10, 3403-3427 (2017) 